\title{
DIVERSITY OF MICROFUNGI ON BRANCHES OF CASTANEA SATIVA IN SLOVAKIA
}

\author{
KATARÍNA ADAMČÍKOVÁ, GABRIELA JUHÁSOVÁ, \\ MAREK KOBZA \& EMÍLIA ONDRUŠKOVÁ
}

\begin{abstract}
Localities in Castanea sativa Mill. plantations were visited in a study aimed at identifying the mycoflora of $C$. sativa in Slovakia [excluding Cryphonectria parasitica (Murr.), Barr for which much data is available]. Samples from chestnut tree branches and stems were examined visually and microscopically. Seven species of microfungi were recorded, three with their anamorphs. Coryneum modonium (Sacc.) Griffon \& Maubl. and Phomopsis castaneae Woron. were the most common. Libertella quercina Tul. \& C. Tul. was identified in both states (anamorph and teleomorph) at two new localities. The records of Gloniopsis praelonga (Schwein.) Underw. \& Earle and Dothidotthia celtidis (Ellis \& Everh.) M. E. Barr are the first for Slovakia. These species were rare, found only in one locality. Two microscopic fungi were detected: Valsa ambiens (Pers.) Fr. [Cytospora ambiens (Nitschke) Sacc.] and Diplodina castaneae Prill. \& Delacr.
\end{abstract}

Key words: European chestnut, microscopic fungi, diversity, Gloniopsis praelonga, Dothidotthia celtidis

Katarína Adamčíková, Gabriela Juhásová, Marek Kobza \& Emília Ondrušková, Institute of Forest Ecology, Slovak Academy of Sciences, Zvolen, Branch for Woody Plant Biology, Nitra, Akademická 2, 94901 Nitra, Slovak Republic; e-mail: katarina. adamcikova@sav.savzv.sk

\section{INTRODUCTION}

European chestnut forms extensive forests, natural and naturalized, from the Caucasus through Turkey to the Balkans and westward to Italy, France, Spain and Portugal. It grows wherever rainfall and soil conditions allow. European chestnut (Castanea sativa Mill.) is an introduced woody plant in Slovakia. Its distribution is scattered and it does not form continuous forests. It is located in areas with warmer climate on downs in south and southeast Slovakia at 200-500 m a.s.1. (Bolvanský et al. 2008). Castanea sativa has been threatened by many parasitic microfungi for several decades, some causing whole chestnut plantations to decline (Juhásová 1999). One of them is Cryphonectria parasitica, which has been causing chestnut blight for more than 70 years throughout Europe (Robin \& Heiniger 2001). There is a large amount of data on its distribution in Slovakia (Adamčíková et al. 2006, 2010; Juhásová \& Bernadovičová 2001) but less about the occurrence of other microfungi on branches or stems of European chestnut.
In this study we surveyed the incidence of microfungi on Castanea sativa branches in different regions of Slovakia, excluding $C$. parasitica for the reason given above. Some are reported as new species for the Slovak mycobiota.

\section{MATERIAL AND METHODS}

Sites with Castanea sativa plantations in Slovakia were visited during our research on fungi inhabiting bark, periderm and wood in 2006-2011 (Table 1). Samples taken from chestnut tree branches were examined visually and microscopically in the laboratory.

We used damp chambers at room temperature to release spores. After dampening the samples with distilled water and incubating them for one day they were observed under a binocular microscope, and fruit bodies were removed for microscopic examination. The morphological structures of microfungi were evaluated and measured on mounts in distilled water. The fungi were identified by the appearance of the fruit bodies and spores under LM.

Spores were scanned with an Olympus Artcam camera and measured to $0.1 \mu \mathrm{m}$ accuracy using Quick 
Table 1. Characteristics of the studied Castanea sativa Mill. sites. A - estimated age of trees, $\mathrm{N}-$ number of $C$. sativa trees. $\mathrm{g}$ - private garden, $\mathrm{f}$ - forest, $\mathrm{o}$ - orchard, $\mathrm{p}$ - public park.

\begin{tabular}{l|c|c|c|c}
\hline Locality & Coordinates & $\mathrm{A}$ & $\mathrm{N}$ & $\begin{array}{c}\text { Type of } \\
\text { stand }\end{array}$ \\
\hline Arborétum Mlyňany, Vieska nad Žitavou & $48^{\circ} 19^{\prime} 30^{\prime \prime} \mathrm{N}, 18^{\circ} 22^{\prime} 15^{\prime \prime} \mathrm{E}$ & 30 & 250 & $\mathrm{o}$ \\
\hline Bratislava Jeséniova & $48^{\circ} 10^{\prime} 09^{\prime \prime} \mathrm{N}, 17^{\circ} 06^{\prime} 15^{\prime \prime} \mathrm{E}$ & $60-120$ & 61 & $\mathrm{p}$ \\
\hline Bratislava Rača & $48^{\circ} 12^{\prime} 35^{\prime \prime} \mathrm{N}, 17^{\circ} 09^{\prime} 24^{\prime \prime} \mathrm{E}$ & $50-60$ & 1 & $\mathrm{~g}$ \\
\hline Suchá nad Parnou & $48^{\circ} 24^{\prime} 33^{\prime \prime} \mathrm{N}, 17^{\circ} 29^{\prime} 25^{\prime \prime} \mathrm{E}$ & $5-10$ & 100 & $\mathrm{o}$ \\
\hline Sološnica & $48^{\circ} 27^{\prime} 54^{\prime \prime} \mathrm{N}, 17^{\circ} 13^{\prime} 52^{\prime \prime} \mathrm{E}$ & 90 & 50 & $\mathrm{f}$ \\
\hline Horné Otrokovce & $48^{\circ} 29^{\prime} 35^{\prime \prime} \mathrm{N}, 17^{\circ} 52^{\prime} 59^{\prime \prime} \mathrm{E}$ & 25 & 1 & $\mathrm{~g}$ \\
\hline Modrý Kameň & $48^{\circ} 14^{\prime} 30^{\prime \prime} \mathrm{N}, 19^{\circ} 20^{\prime} 20^{\prime \prime} \mathrm{E}$ & $30-35$ & 216 & $\mathrm{o}$ \\
\hline Svätý Jur & $48^{\circ} 15^{\prime} 02^{\prime \prime} \mathrm{N}, 17^{\circ} 11^{\prime} 42^{\prime \prime} \mathrm{E}$ & $10-100$ & 35 & $\mathrm{~g}$ \\
\hline
\end{tabular}

Micro Photo ver. 2.1. Enlarged images of spores were used for measurement. Species determination followed the keys of Bánhegyi et al. (1985), Ellis and Ellis (1997) and Grove $(1935,1937)$, and fungal nomenclature follows Index Fungorum.

\section{RESULTS}

We recorded seven microscopic fungi during our research on Castanea sativa in Slovakia. The species are given below.

Melanconis modonia Tul. \& C. Tul.

Coryneum modonium (Sacc.) Griffon \& Maubl.

This fungus was determined in both its states. The anamorph, C. modonium, was most common. It was found on dead branches. Acervuli are pulvinate, dark brown to black, up to $0.5 \mathrm{~mm}$ in diameter, embedded in bark tissues. Conidia are slightly curved, fusiform, pale brown, with 3 to 7 pseudosepta, $15-21 \times 43-72 \mu \mathrm{m}$. Perithecia are black, deeply embedded in stromata. Ascospores are hyaline, with one septum, 26-38 $\times 8-12 \mu \mathrm{m}$. This was the fungus most commonly observed (Table 2).

\section{Phomopsis castaneae Woron.}

Pycnidia, found in dead tissues, are black to grey. Two types of spores, both of which hyaline and one-celled, are produced in each pycnidium. One type, called $\alpha$ conidia, are ellipsoid to fusi- form, germinate easily, and contain two oil guttules at each end of the spore. The second, called $\beta$ conidia, are curvilinear and did not germinate. $\alpha$ conidia measure $10-12 \times 2.0-2.5 \mu \mathrm{m}$, and $\beta$ conidia $30-38 \times 1-2 \mu \mathrm{m}$.

Symptoms of Ph. castaneae are commonly seen on European chestnut in Slovakia, but during this research the fruit bodies were identified at three localities (Table 2).

\section{Diatrypella quercina (Pers.) Cooke}

Libertella quercina Tul. \& C. Tul.

This fungus was found as teleomorph and anamorph. Present in the bark were conidial stromata of the fungus, in the form of glossy red-orange subepidermal acervuli. In moist conditions the conidia are released from the acervuli in a sticky orange substance. This substance contains long, curved, hyaline conidia, $23.9-41.2 \times 0.7-0.8 \mu \mathrm{m}$.

This fungus was detected in both states at two localities (Suchá nad Parnou, Bratislava, Table 2). The perithecia of $D$. quercina are dark brown to black, up to $0.6-0.7 \mathrm{~mm}$ in diameter. The asci are polysporous. The ascospores are curved, hyaline, and pale gold to brown in mass, $8-12 \times 2-3 \mu \mathrm{m}$.

Valsa ambiens (Pers.) Fr.

Cytospora ambiens (Nitschke) Sacc.

Both states of this fungus were found on young living twigs. Stromata of the anamorph state are 
visible to the naked eye as slightly conical formations $0.3-0.6 \mathrm{~mm}$ in diameter. The stromata are yellow at first, later brown to black, and pale or white on the margin. Conidia are tiny, slightly curved, hyaline, single-celled, 6-7 $\times 1 \mu \mathrm{m}$. The conidia are released from conidiomata in moist conditions as curling orange-yellow tendrils. The perithecia of $V$. ambiens are formed in the same stromata as pycnidia or separately. Erumpent ectostromatal discs are dark grey, grey or pale grey. Asci are 8-spored. Ascospores are allantoid, hyaline, one-celled, $22-27 \times 5-8 \mu \mathrm{m}$. This species was found at two localities during the study (Table 2).

Gloniopsis praelonga (Schwein.) Underw. \& Earle

It was detected at only one locality (Bratislava, Table 2). Black fruit bodies were formed on the bark surface. They are brittle, ellipsoid to elongated, $1.5 \mathrm{~mm}$ long and $0.3-0.4 \mathrm{~mm}$ wide. One ascus contains eight ascospores. Ascospores are $24-31 \times 12-14 \mu \mathrm{m}$, with 5 to 7 (sometimes more) transverse septa and 1 to 4 longitudinal septa.

Dothidotthia celtidis (Ellis \& Everh.) M. E. Barr

Pseudothecia are solitary, immersed, dark, up to $0.4 \mathrm{~mm}$ in diameter. Asci are cylindrical to clavate, with 8 spores, $115-125 \times 16-18 \mu \mathrm{m}$. Ascospores are dark brown, ellipsoid, with a thick smooth wall, one-septate, not or sometimes slightly constricted at the septum, 19-22 × 9-11 $\mu \mathrm{m}$. It was found at only one locality on dead branches (Table 2).

Diplodina castaneae Prill. \& Delacr.

This fungus was detected only in its anamorph state (D. castaneae); the teleomorph state was not recorded (Table 2). It was identified on angular cracks in bark of dead branches. The conidiomata of the fungus are dark subepidermal pycnidia. Conidia are released under wet conditions as flesh-colored tendrils which are hyaline, fusiform, 10-13 × 1-3 $\mu \mathrm{m}$ (mean $10.9 \times 1.96$ ), with one septum.

Table 2. List of microfungi recorded on European chestnut during the study period at sites in Slovakia. $\mathrm{t}-$ teleomorph, a anamorph.

\begin{tabular}{|c|c|c|c|}
\hline Fungus & Date of sampling & $\mathrm{t} / \mathrm{a}$ & Locality \\
\hline \multirow{5}{*}{$\begin{array}{l}\text { Melanconis modonia Tul. \& C. Tul., } \\
\text { Coryneum modonium (Sacc.) Griffon \& Maubl. }\end{array}$} & 8 April 2008 & $\mathrm{a}$ & Arborétum Mlyňany, Vieska nad Žitavou \\
\hline & 22 May 2011 & $\mathrm{a}$ & Suchá nad Parnou \\
\hline & 29 June 2009 & $\mathrm{a}$ & Sološnica \\
\hline & 23 May 2006 & $\mathrm{a}$ & Horné Otrokovce \\
\hline & 20 April 2010 & $\mathrm{a} / \mathrm{t}$ & Modrý Kameň \\
\hline \multirow{2}{*}{$\begin{array}{l}\text { Valsa ambiens (Pers.) Fr., } \\
\text { Cytospora leucosperma (Pers.) Fr. }\end{array}$} & 26 September 2011 & $\mathrm{a} / \mathrm{t}$ & Suchá nad Parnou \\
\hline & 22 October 2010 & $\mathrm{a} / \mathrm{t}$ & Modrý Kameň \\
\hline \multirow{3}{*}{$\begin{array}{l}\text { Diaporthe eres Nitschke, } \\
\text { Phomopsis castaneae Woron. }\end{array}$} & 19 April 2010 & $\mathrm{a}$ & Modrý Kameň \\
\hline & 5 June 2007 & $\mathrm{a}$ & Arboretum Mlyňany, Vieska nad Žitavou \\
\hline & 26 September 2011 & $\mathrm{a}$ & Suchá nad Parnou \\
\hline \multirow{3}{*}{$\begin{array}{l}\text { Diatrypella quercina (Pers.) Cooke } \\
\text { Libertella quercina Tul. \& C. Tul. }\end{array}$} & 22 September 2010 & $\mathrm{a} / \mathrm{t}$ & Suchá nad Parnou \\
\hline & 28 June 2006 & $\mathrm{a}$ & Horné Otrokovce \\
\hline & 8 April 2011 & $\mathrm{a} / \mathrm{t}$ & Bratislava, Jeséniova \\
\hline Gloniopsis praelonga (Schwein.) Underw. \& Earle & 21 April 2011 & $\mathrm{t}$ & Bratislava Rača \\
\hline Dothidotthia celtidis (Ellis \& Everh.) M. E. Barr & 19 September 2011 & $\mathrm{t}$ & Svätý Jur \\
\hline \multirow{2}{*}{$\begin{array}{l}\text { Diplodina castaneae Prill. \& Delacr., } \\
\text { Cryptodiaporthe castanea (Tul. \& C. Tul.) Wehm. }\end{array}$} & 19 April 2010 & a & Modrý Kameň \\
\hline & 26 September 2011 & a & Suchá nad Parnou \\
\hline
\end{tabular}




\section{DISCUSSION}

Melanconis modonia (Coryneum modonium) was the most common microscopic fungus determined on branches of European chestnut in Slovakia (except for Cryphonectria parasitica; Juhásová et al. 2005). It was first recorded in Slovakia in 1974 in Zemberovce. Both states (teleomorph and anamorph) were recorded on dead and weakened branches and rarely on stems (Juhásová 1978). In the following years it was noted from all studied localities on weakened trees cultivated in unsuitable conditions (Juhásová 1999). It is an endophytic, nonpathogenic fungus (Bissegger \& Sieber 1994). M. modonia has been reported on European chestnut in other European countries: Switzerland, Bulgaria, Romania, France and Belgium (Farr \& Rossman 2013). Diffuse cankers caused by $M$. modonia were recorded previously in Portugal, but only on senescent bark or on chestnuts weakened by biotic and abiotic factors. During 1995 , however, there was a widespread and unexpected outbreak of diffuse canker on young chestnuts; high infection by $M$. modonia caused significant economic loss in chestnut orchards in Portugal (Abreu 1996). The fungus has been recorded on Castanea species other than C. sativa, and on other woody plant species (Farr \& Rossman 2013).

Phomopsis castaneae is another common microfungus on European chestnut in Slovakia. It was found frequently during earlier research in 1965-1991 at 45 localities throughout Slovakia (Juhásová 1992), but was not included in the Checklist of non-vascular and vascular plants of Slovakia (Lizoň \& Bacigálová 1998). Two of the three localities recorded in this paper (Modrý Kameň, Arborétum Mlyňany) were also reported by Juhásová (1992). The new one is Suchá nad Parnou, where a new chestnut orchard was planted in 2007. The fungus was recorded mainly on seedlings and young trees with smooth bark (Juhásová 1999). Phomopsis is an endophyte not known to be a chestnut pathogen (Bissegger \& Sieber 1994). According to Juhásová (1999) it causes cankers and withering of branches and young stems. The teleomorph state (Diaporthe) was not detected during our research. It has been described from
Ukraine, France, Germany and Italy on C. sativa, and on dead branches of Castanea dentata from the United States (Farr \& Rossman 2013). Besides occurring on branches, $P$. castanea has also been identified in nuts. It occurred as an endophyte in stems (except xylem), leaves, flowers and immature burrs of chestnut trees (Wadia et al. 2000).

Libertella quercina was first determined on European chestnut in Slovakia in 2006, on dead branches; it has not been successfully isolated and its pathogenicity to chestnut is unknown (Adamčíková et al. 2011). During this study it was detected in both states at other two localities. Saccardo (1906) reported Cytosporina quercina (Tul. \& Tul.) Traverso (=Libertella quercina Tul. \& Tul.) on branches of Quercus and Castanea in Italy, France and Germany, with conidia described as cylindric-filiform, arched curved, hyaline, 30-35 $\times$ 1.0-1.5 $\mu \mathrm{m}$. Libertella quercina has been reported from England (Grove 1937), Lithuania (Irsenaite \& Treigiene 2001) and Hungary (Magyar \& Tóth 2003). Acervuli of L. quercina occurred abundantly on Quercus bark in England and France (Grove 1937). Diatrypella quercina, the teleomorph state of the anamorph L. quercina (Grove 1937), was recorded on more woody plant species in eastern North America and Europe.

Valsa ambiens and Cytospora ambiens are cosmopolitan microfungi causing canker disease of hardwood trees, especially those stressed or damaged (Sivanesan \& Holliday 1970; Hayova \& Minter 1998a, b). Two species of Cytospora have been recorded on C. sativa: C. ambiens (Spaulding 1961) and C. cerathophora (Truszkowska \& Chlebicki 1983). Saccardo (1879) described C. ambiens conidia (hyaline, $6 \times 1 \mu \mathrm{m}$, sausage-shaped) on branches of Juglans and Tilia, and C. ceratophora conidia ( $4 \times 1 \mu \mathrm{m}$, sausage-shaped) on branches of Fraxinus. C. leucosperma is common on bark of Castanea twigs and branches; the spores are sausage-shaped, 5-7 $\times 1 \mu \mathrm{m}$, issuing white, then yellowish tendrils or mass (Grove 1935). In Europe C. ambiens has been determined on C. sativa in Belgium and on $C$. crenata in France (Farr \& Rossman 2013). Juhásová (1992) recorded $C$. intermedia as a cause of branch withering in European chestnut at 28 localities in Slovakia; the conidia were described 
as crescent-shaped, colorless, 4-5 × 1-2 $\mu \mathrm{m}$. Valsa ambiens was recorded on Castanea species in Japan (Farr \& Rossman 2013).

Our present reports of Gloniopsis praelonga and Dothidotthia celtidis on C. sativa in Slovakia are the first for Slovakia. There are no published data on the occurrence of G. praelonga and D. celtidis in Slovakia; nor are they noted in the Checklist of non-vascular and vascular plants of Slovakia (Lizoň \& Bacigálová 1998). Each was found at a single locality. G. praelonga is a cosmopolitan fungus recorded on many woody plant species. On C. sativa it has been reported from Portugal, Spain (Farr \& Rossman 2013) and Hungary (Bánhegyi et al. 1985).

Didymosphaeria superapplanata Sivan. (= Dothidotthia celtidis) was described in 1977 on branches of C. sativa (Sivanesan 1977). Pseudothecia are scattered, immersed, erumpent, black, $360-400 \times 350-380 \mu \mathrm{m}$, globose. Asci are cylindrical to cylindric-clavate, thick-walled, 8-spored, 115-125 × 16-18 $\mu \mathrm{m}$. Ascospores are brown, ellipsoidal, septate, not constricted or sometimes slightly constricted at septum, smooth, 20-25 $\times$ 5-11 $\mu \mathrm{m}$, tapering to connate or rounded ends (Sivanesan 1977). It was also reported on Castanea sp. in the United Kingdom by Cannon et al. (1985) and by Ellis and Ellis (1997). Barr (1989) described this fungus as $D$. celtidis with ascomata immersed, scattered to gregarious, sphaeroid, $220-440 \mu \mathrm{m}$ in diameter, asci 60-70 $\times 25-28 \mu \mathrm{m}$, ascospores 19-27 × 9.0-12.5 $\mu \mathrm{m}$, dark brown, broadly ellipsoid, (0-)1-septate, not constricted, wall thick, smooth.

Diplodina castaneae was observed on young branches of $C$. sativa as a very harmful species: spores 6-7 × 1-1.5 $\mu \mathrm{m}, 1$-septate (Saccardo 1895). Conidial size is $9-12 \times 2.5-3.0 \mu \mathrm{m}$ according to Day (1930), but 6-7 $\times 1-1.5 \mu \mathrm{m}$ in the original description (Prillieux \& Delacroix 1893). Grove (1935) adopted the latter measurements but noted the possibility of error. Ellis and Ellis (1997) described both states of this fungus. The Diplodina state was found on dead branches and twigs between May and October. It causes Javart disease of European chestnut (Prillieux \& Delacroix 1893). According to Day (1930) this disease is character- ized by small cankers on the stem of young coppice shoots, which are sometimes killed. The conidia are issued in flesh-colored tendrils, mostly 8-12 $\times 2-3 \mu \mathrm{m}$, and remain without a septum except in longer conidia just before germination (Ellis \& Ellis 1997). We did not observe this dimorphism of conidia; nor did Bissegger and Sieber (1994), who gave the conidia dimensions as 8-13 $\times 2.0-2.5 \mu \mathrm{m}$. The fungus was recorded in the area of present-day France, Belgium, northern Italy and Germany (Saccardo 1895), and more recent records come from Bulgaria and Switzerland (Vanev et al. 1997; Bissegger \& Sieber 1994). The fungus was also reported on C. crenata in Japan (Farr \& Rossman 2013). It was first found in Slovakia in 1998 at Horné Lefantovce on seedlings and young trees, causing necrosis well visible on smooth bark (Juhásová 1999); it was not included in the Checklist of non-vascular and vascular plants of Slovakia (Lizoň \& Bacigálová 1998). The teleomorph state (as Cryptodiaporthe castaneae) forms black clustered perithecia up to $0.8 \mathrm{~mm}$ in diameter. Ascospores are hyaline, appendaged, one-septate, 13-18 × 2-4 $\mu \mathrm{m}$ (Ellis $\&$ Ellis 1997). We did not record the teleomorph during this study. It is considered to be a weak wound parasite sometimes causing dieback and cankers (Bissegger \& Sieber 1994).

In this study we recorded seven different fungal species. Some of them co-occurred with the chestnut blight fungus $C$. parasitica. Their joint effect could be the reason for the poor health, drying and death of Castanea sativa.

ACKNOWLEDGMENTS. We are grateful to the anonymous reviewers for valuable remarks on the manuscript. This study was funded by the Slovak VEGA Grant Agency (project 2/0149/10).

\section{REFERENCES}

ABREU C. G. 1996. Recent outbreak of bark canker caused by Melanconis modonia on European chestnut in northern Portugal. Plant Disease 80: 1-301.

ADAMČíKovÁ K., JuHÁsovÁ G. \& KoBZA M. 2006. Genetic diversity of Cryphonectria parasitica population in the Štiavnicko-krupinská subpopulation in Slovakia. Plant Protection Science 42: 119-124. 
ADAMČíKovÁ K., KoBZA M. \& JuHÁSOvÁ G. 2010. Characteristics of Cryphonectria parasitica isolated from Quercus in Slovakia. Forest Pathology 40: 443-449.

ADAMČíKovÁ K., KobZa M. \& JuHÁsovÁ G. 2011. The first report of Libertella spp. on Fagaceae in Slovakia. Mycoscience 52: 268-270.

BANHÉGYi J., TóTH S., UbRizSY G. \& VÖRÖS J. 1985. Magyarország mikroszkopikus gombáinak határozókönyve. 1-3. Akadémiai Kiadó, Budapest.

BissegGer M. \& Sieber T. N. 1994. Assemblages of endophytic fungi in coppice shoots of Castanea sativa. Mycologia 86: 648-655.

BolvanskÝ M., Brindza J., Tóth D., BACigÁlová K., FeRiAnC P., Karelová E., Harichová J., KaČÁNiová M., HorČIn V., MENDEL L'. \& UŽíK M. 2008. Gaštan jedlý (Castanea sativa Mill.) biológia, pestovanie a využívanie. Agrobiodiverzita, Nitra.

CAnNon P. F., Hawksworth D. L. \& Sherwood-Pike M. A. 1985. The British Ascomycotina. An Annotated Checklist. Commonwealth Mycological Institute, Kew, Surrey.

CHeCA J. 2004. Flora Mycologica Iberica. 6. Dictyosporic Dothideales. J. Cramer, Madrid.

DAY W. R. 1930. The 'Javart' disease of sweet chestnut. Quart. J. Forest 24: 114-117.

Ellis M. B. \& ELLIS J. P. 1997. Microfungi on land plants. Richmond Publishing, Slough.

FARR D. F. \& Rossman A. Y. 2013. Fungal Databases, Systematic Mycology and Microbiology Laboratory, ARS, USDA. [July 17, 2012]. http://nt.ars-grin.gov/fungaldatabases.

Grove W. B. 1935. British stem- and leaf-fungi (Coelomycetes). 1. Cambridge University Press, Cambridge.

Grove W. B. 1937. British stem- and leaf-fungi (Coelomycetes). 2. Cambridge University Press, Cambridge.

Hayova V. P. \& Minter D. W. 1998a. Valsa ambiens subsp. ambiens. IMI Descriptions of Fungi and Bacteria 137: Sheet 1364.

Hayova V. P. \& Minter D. W. 1998b. Valsa ambiens subsp. leucostomoides. IMI Descriptions of Fungi and Bacteria 137: Sheet 1365.

IRSENAITE R. \& TREIGIENE A. 2001. Pyrenomycetes and Loculoascomycetes on oak (Quercus) in Lithuania. Botanica Lithuanica 7: 193-202.

JuHÁsOVÁ G. 1978. Pathogenicity of the fungi Melanconis modonia Tul. and Phytophthora cambivora (Petri) Buism. on European chestnut. Acta Botanica Slovaca, Series B 2: 237-249 (in Slovak with English summary).

JUHÁSOVÁ G. 1992. A summary of knowledge on fungal diseases of Spanish chestnut in Slovakia. Lesnictvi-Forestry 38: 449-460 (in Slovak with English summary).
JuHÁsOvÁ G. 1999. Fungal diseases of European chestnut (Castanea sativa Mill.). Veda, Bratislava (in Slovak with English summary).

JuhÁsovÁ G. \& BERNAdOviČOVÁ S. 2001. Cryphonectria parasitica (Murr.) Barr and Phytophthora spp. in chestnut (Castanea sativa Mill.) in Slovakia. Forest Snow and Landscape Research 76: 373-377.

JuhÁsovÁ G., Kobza M. \& AdAmčíkovÁ K. 2005. Diversity of Cryphonectria parasitica (Murr.) Barr vegetative compatibility (vc) types in Slovakia. Acta Hort. 693: 635-640.

Lizoň P. \& BaCigÁlovÁ K. (eds) 1998. Huby. Fungi. In: K. MARHOLD \& F. HINDÁK (eds), Checklist of non-vascular and vascular plants of Slovakia, pp. 102-227. Veda, Bratislava.

MAgYaR D. \& Tóth S. 2003. Data to the knowledge of the microscopic fungi in the forests around Budakeszi (Buda Hills, Hungary). Acta Phytopathologica et Entomologica Hungarica 38: 61-72.

PrillieuX E. E. \& Delacroix E. G. 1893. Le Javart, maladie des chataigniers. Bull. Soc. Mycol. France 9: 275-277.

Robin C. \& HeINIGer U. 2001. Chestnut blight in Europe: diversity of Cryphonectria parasitica, hypovirulence and biocontrol. Forest Snow and Landscape Research 76: 361-367.

SACCARDO P. A. 1879. Fungi Gallici lecti a cl. viris P. Brunaud, C.C. Gillet et Abb. Letendre. Michelia 1(5): 500-538.

SACCARDo P. A. 1895. Sylloge Fungorum. 11. Sumptibus Auctoris, Patavii.

SACCARDo P. A. 1906. Sylloge Fungorum. 18. Sumptibus P. A. Saccardo, Patavii.

Sivanesan A. \& HollidaY P. 1970. Valsa eugeniae. IMI Descriptions of Fungi and Bacteria 23: Sheet 230.

Sivanesan A. 1977. British Ascomycetes. Trans. Brit. Mycol. Soc. 69: 1-122.

TruSZKOWSKA W. \& CHLEBICKI A. 1983. Pyrenomycètes dans le associations forestières de cotoaux de Strzelin (Basse Silesie). Acta Mycol. 19: 129-157 (in Polish with French summary).

VAnev S. G., SAmeva E. F. \& BaKalova G. G. 1997. Fungi Bulgaricae. Ordo Sphaeropsidales 3(1). Editio Academica "Prof. Marin Drinov," Editio "Pensoft," Sofia (in Bulgarian with English summary).

WADIA K. D. R., KLINAC D., MCNEIL D. L., OSMONALIEVA A., STEWART A. \& KNOWLES R. D. 2000. Occurrence of Phomopsis castanea as an endophyte in chestnut trees. New Zealand Plant Protection 53: 133-137. 